Western University

Scholarship@Western

Obstetrics \& Gynaecology Publications

Obstetrics \& Gynaecology Department

$2-1-2000$

Impact of bovine oocyte maturation media on oocyte transcript levels, blastocyst development, cell number, and apoptosis.
AJ Watson
P De Sousa
A Caveney
L C Barcroft
D Natale

See next page for additional authors

Follow this and additional works at: https://ir.lib.uwo.ca/obsgynpub

Part of the Obstetrics and Gynecology Commons

Citation of this paper:

Watson, A J; De Sousa, P; Caveney, A; Barcroft, L C; Natale, D; Urquhart, J; and Westhusin, M E, "Impact of bovine oocyte maturation media on oocyte transcript levels, blastocyst development, cell number, and apoptosis." (2000). Obstetrics \& Gynaecology Publications. 67.

https://ir.lib.uwo.ca/obsgynpub/67 
Authors

A J Watson, P De Sousa, A Caveney, L C Barcroft, D Natale, J Urquhart, and M E Westhusin 


\title{
Impact of Bovine Oocyte Maturation Media on Oocyte Transcript Levels, Blastocyst Development, Cell Number, and Apoptosis ${ }^{1}$
}

\author{
Andrew J. Watson, 2,4,5 Paul De Sousa,,3,5 Anita Caveney, ${ }^{4,5}$ Lisa C. Barcroft,, ${ }^{4,5}$ David Natale, ${ }^{4,5}$ \\ Jennifer Urquhart, ${ }^{4,5}$ and Mark E. Westhusin ${ }^{6}$ \\ Departments of Obstetrics and Gynaecology ${ }^{4}$ and Physiology, ${ }^{5}$ The University of Western Ontario, London, Ontario, \\ Canada N6A 5C1 \\ Department of Veterinary Physiology and Pharmacology, ${ }^{6}$ College of Veterinary Medicine, Texas A\&M University, \\ College Station, Texas 77843-4466
}

\begin{abstract}
The objectives were 1) to investigate the effects of oocyte maturation in serum-free and amino acid-supplemented defined media on oocyte transcript levels, blastocyst cell number, and apoptosis; 2) to investigate the influence of oocyte maturation culture atmosphere on blastocyst development, total cell number, and apoptosis; and 3) to examine the influence of epidermal growth factor (EGF) during oocyte maturation on blastocyst cell number and apoptosis. The results demonstrate that blastocysts derived from in vitro maturation, fertilization, and embryo culture protocols undergo apoptosis but that apoptotic levels are not greatly influenced by the oocyte maturation environment. Amino acid supplementation of oocyte maturation media was associated with enhanced developmental frequencies, increased blastocyst cell number, and elevated oocyte maternal mRNA levels. Oocyte maturation with supplemented synthetic oviduct fluid medium (cSOFMaa) resulted in blastocyst cell numbers comparable to those observed with Tissue Culture Medium $199+$ newborn calf serum. Blastocyst development was reduced following oocyte maturation under a $5 \% \mathrm{CO}_{2}, 7 \% \mathrm{O}_{2}, 88 \% \mathrm{~N}_{2}$ culture atmosphere. EGF supplementation of oocyte maturation medium resulted in a concentration-dependent increase in blastocyst development but did not influence blastocyst total cell number or apoptosis. Our findings indicate that cSOFMaa medium is an effective base medium for bovine oocyte maturation.
\end{abstract}

\section{INTRODUCTION}

Research investigating oocyte maturation, fertilization, and embryonic development is necessary for improved assisted-reproduction technologies in animals and humans and to reveal the causes of abnormal embryonic development [1-4]. Broad variation exists in development frequency in vitro for early embryos from different mammalian species. Effective defined media (most notably CZB and KSOMaa) were first developed for the murine early embryo [5-8]. Development of bovine embryos to the blastocyst stage can be readily supported by employing serum-sup-

${ }^{1}$ This work was supported by the National Institute of Child Health and
Human Development, National Cooperative Program on Non-Human In
Vitro Fertilization and Embryo Development, USA. P.D. was supported by
an Organon, Canada, Inc., Postdoctoral Fellowship in Reproductive En-
docrinology; L.C.B. is the recipient of a NSERC Postgraduate Scholarship.
${ }^{2}$ Correspondence. FAX: 5196613827 ;
e-mail: awatson@physiology.uwo.ca
${ }^{3}$ Current address: Geron Bio-Med, Roslin Institute, Roslin, Midlothian, ${ }^{3}$ Curre.

Received: 19 April 1999.

First decision: 13 May 1999.

Accepted: 9 September 1999.

(C) 2000 by the Society for the Study of Reproduction, Inc.

ISSN: 0006-3363. http://www.biolreprod.org plementation of media and oviduct coculture under a $5 \%$ $\mathrm{CO}_{2}$-in-air atmosphere [9-14]. This reliance upon coculture is eliminated when reduced- $\mathrm{O}_{2}$ culture atmospheres are employed, and this has led to the characterization of defined serum-free conditions that effectively support bovine embryo development in vitro [15-18].

Methods for supporting maturation of bovine cumulusoocyte complexes (COCs) in vitro have employed Tissue Culture Medium 199 (TCM199) supplemented with 10\% serum, gonadotropins, and estradiol-17 $\beta$ [8,11-14]. These conditions support meiotic maturation of approximately $90 \%$ of oocytes and set the stage for high fertilization frequencies and development through to the blastocyst stage. An obvious concern exists, however, regarding the inherent undefined qualities of serum $[2,4,18]$. To characterize specific requirements for oocyte maturation, serum-free systems must be developed. This has been the subject of recent intensive research, and several groups have reported successful development of bovine embryos through to the blastocyst stage following oocyte maturation in serum-free conditions [18-25]. These studies have reported influences of amino acid supplementation and culture atmosphere on developmental frequencies and embryo metabolism [18-25]. Studies have not, however, examined influences of serumfree oocyte maturation on oocyte transcript levels or blastocyst cell number and apoptosis. Cell number and apoptosis levels are important parameters that are emerging as useful indicators of embryo development and health [2628]. The objectives of the present study were 1) to investigate the effects of oocyte maturation in serum-free and amino acid-supplemented defined media on oocyte transcript levels, blastocyst cell number, and apoptosis; 2) to investigate the influence of oocyte maturation culture atmosphere on blastocyst development, total cell number, and apoptosis; and 3) to examine the influence of epidermal growth factor (EGF) during oocyte maturation on blastocyst cell number and apoptosis.

\section{MATERIALS AND METHODS}

\section{Oocyte Collection, Insemination, and Embryo Culture}

COCs were collected by razor blade slashing of slaughterhouse ovaries within $4 \mathrm{~h}$ of removal from the animal $[13,29]$. The COCs were collected in oocyte collection medium (Hepes-buffered TCM199 + 2\% v:v newborn calf serum [NCS]; Gibco BRL, Burlington, ON, Canada) and then were washed 4 times in serum-free medium prior to placement in oocyte maturation medium. Only denuded oocytes were discarded, and a COC selection strategy was not employed in this study. After oocyte maturation (see below for specific experimental conditions), oocytes were insem- 
inated in vitro with frozen-thawed bovine semen (Semex Canada, Guelph, ON, Canada) prepared using a "swim-up" method in sperm TL medium (Hepes-buffered modified Tyrode's solution as described previously [30]). Matured COCs were washed in sperm TL and placed in equilibrated fertilization drops (50 COCs/300- $\mu$ l drop) composed of bicarbonate-buffered modified Tyrode's solution under light paraffin oil ([30]; BDH, Toronto, ON, Canada). COCs and sperm $\left(2.25 \times 10^{5}\right.$ motile spermatozoa per drop $)$ were incubated for $18 \mathrm{~h}$ at $39^{\circ} \mathrm{C}$ under $5 \% \mathrm{CO}_{2}$-in-air atmosphere before removal, with a fine-bore glass pipette, of the cumulus investment including all corona cells. Inseminated oocytes (40-50) were placed into embryo culture consisting initially of $20-\mu 1$ microdrops of citrate $(0.5 \mathrm{mM})$-supplemented and polyvinyl alcohol (PVA; $3 \mathrm{mg} / \mathrm{ml}$ )-supplemented synthetic oviduct fluid medium (cSOFMaa) $[15,16]$ + single-strength nonessential amino acids (NEA; SigmaAldrich Canada Ltd, Oakville, ON, Canada) and singlestrength essential amino acids (MEM; Gibco BRL) under paraffin oil in a humidified $5 \% \mathrm{CO}_{2}, 7 \% \mathrm{O}_{2}, 88 \% \mathrm{~N}_{2}$ culture atmosphere. Two days after initiation of culture, the microdrops were increased in volume by addition of $20 \mu \mathrm{l}$ of cSOFMaa medium. On Days 5 and 7 of culture, $20 \mu \mathrm{l}$ of medium was removed from each and replaced with 20 $\mu l$ of fresh medium; this kept the microdrop volume constant for the remainder of the 8-day culture interval. Cleavage and blastocyst frequencies were assessed on Days 3 and 8 postinsemination, respectively.

\section{Experimental Design}

Experiments employed a randomized design that allocated equivalent numbers of nonselected COCs to each oocyte maturation treatment group.

In experiment 1 , a total of 2950 COCs (40-50 COCs per treatment per replicate) were placed into individual wells of 4-well culture plates containing $0.5 \mathrm{ml}$ of either 1) TCM199+10\% NCS (T199+NCS); 2) cSOFM+10\% NCS (cSOFM+NCS); 3) cSOFM+ single-strength essential (EAA) and nonessential (NEA) amino acids (cSOFMaa); and 4) cSOFM minus amino acids (cSOFM). All media were supplemented with $1 \mu \mathrm{g} / \mathrm{ml} \mathrm{FSH} \mathrm{(Follitropin;} \mathrm{Vetra-}$ pharm, London, ON, Canada), $5 \mu \mathrm{g} / \mathrm{ml} \mathrm{LH}$ (Vetrapharm), and $1 \mu \mathrm{g} / \mathrm{ml}$ estradiol-17 $\beta$ (Sigma-Aldrich). Fifteen replicate experiments were conducted employing a $5 \% \mathrm{CO}_{2}$-inair atmosphere at $39^{\circ} \mathrm{C}$. After maturation, one tenth (i.e., 4-5 oocytes from each treatment) of the matured oocytes from each replicate were frozen in lysis buffer for RNA analysis (see below). The remaining oocytes in each treatment were inseminated, and zygotes were placed into culture for assessment of developmental frequencies, blastocyst cell number, and apoptosis.

In experiment 2, a total of 1518 COCs were allocated to oocyte maturation treatment groups. COCs (35-50 COCs per treatment per replicate) were placed into individual wells of 4-well culture plates containing $0.5 \mathrm{ml}$ of either 1) cSOFMaa or 2) cSOFM. All treatments were supplemented with $1 \mu \mathrm{g} / \mathrm{ml} \mathrm{FSH}, 5 \mu \mathrm{g} / \mathrm{ml} \mathrm{LH}$, and $1 \mu \mathrm{g} / \mathrm{ml}$ estradiol$17 \beta$. Fourteen replicate experiments were conducted in which half of the COCs (including both + and - amino acid groups) were matured under a $5 \% \mathrm{CO}_{2}, 7 \% \mathrm{O}_{2}, 88 \%$ $\mathrm{N}_{2}$ culture atmosphere and the other half under a $5 \% \mathrm{CO}_{2^{-}}$ in-air culture atmosphere. After maturation, oocyte pools were inseminated, and cleavage and frequency of development to the blastocyst stage, blastocyst cell number, and apoptosis were measured.
In experiment 3 , a total of 471 COCs were allocated to oocyte maturation treatment groups. COCs (35-40 COCs per treatment per replicate) were placed into individual wells of 4-well culture plates containing $0.5 \mathrm{ml}$ of either 1) cSOFMaa alone or cSOFMaa supplemented with either 1, 10 , or $100 \mathrm{ng} / \mathrm{ml}$ of murine EGF (Sigma-Aldrich). None of these four treatments were supplemented with gonadotropins or estradiol-17 $\beta$. Three replicate experiments were conducted under a $5 \% \mathrm{CO}_{2}$-in-air culture atmosphere. For this experiment, influences on cumulus cell expansion were determined along with cleavage, frequency of development to the blastocyst stage, blastocyst cell number, and apoptosis.

\section{Terminal Deoxynucleotidyl Transferase-Mediated dUTP Nick End-Labeling (TUNEL) and Propidium lodide Labeling}

Zona pellucida-intact Day 8 (postinsemination) blastocysts were fixed in $1 \%$ paraformaldehyde in PBS, $\mathrm{pH}$ 7.4, for $1 \mathrm{~h}$ at room temperature. The blastocysts were washed

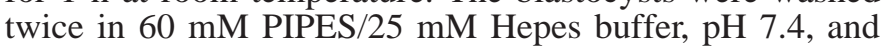
stored in the second wash in a sealed 4-well plate at $4^{\circ} \mathrm{C}$ until ready for labeling. An in situ cell death detection kit using fluorescein-conjugated dUTP and TUNEL (Roche Molecular Biochemicals, Laval, PQ, Canada) was used for labeling apoptotic cells. Blastocysts were washed with PBS and then permeabilized with $0.1 \%$ Triton $\mathrm{X}-100$ in $0.1 \%$ sodium citrate for $15 \mathrm{~min}$; they were then washed twice with PBS before labeling. Positive control embryos were treated with $50 \mathrm{U} / \mathrm{ml} \mathrm{RQ} 1 \mathrm{RNase}$-free DNase for $20 \mathrm{~min}$ at $37^{\circ} \mathrm{C}$ and then washed twice with PBS prior to labeling. The TUNEL reagent was prepared immediately before use and kept on ice. Blastocysts were placed in 50- $\mu$ l drops of TUNEL reagent, covered with filtered paraffin oil, in 35$\mathrm{mm}$ Petri dishes and incubated in the dark at $37^{\circ} \mathrm{C}$ for 60 min in a humidified chamber. The blastocysts were washed three times with $1 \%$ BSA in PBS and incubated with 50 $\mu \mathrm{g} / \mathrm{ml}$ RNase A in the dark at room temperature for 60 $\mathrm{min}$. Total cell nuclei were labeled with $40 \mu \mathrm{g} / \mathrm{ml}$ propidium iodide (Sigma-Aldrich) in sterile $\mathrm{H}_{2} \mathrm{O}$ in the dark at room temperature for $60 \mathrm{~min}$. The embryos were washed twice with $1 \%$ BSA in PBS and mounted in fluoroguard antifade mounting reagent (Bio-Rad, Mississauga, ON, Canada).

\section{Imaging Microscopy and Analysis}

Initially, the blastocysts were viewed with confocal microscopy; however, this proved to be inefficient for accurate cell counting of total nuclei in Day 8 bovine blastocysts. We instead adapted standard epifluorescence microscopy methods applied to flattened blastocysts to generate digitized images that were analyzed with Northern Exposure image analysis software (Empix Imaging, Mississauga, ON, Canada) to quantify cell counts. Digital still images were captured through an integrating Sony (Park Ridge, NJ) XC75 CCD video camera module. The camera was controlled through a personal computer (PII-400, 128 MB RAM, 8.4 GB HD, Hewlett-Packard 800 series CD-writer; Palo Alto, $\mathrm{CA}$ ) running Empix Imaging software. Images of the fluorescein-labeled apoptotic cells and the propidium iodidelabeled nuclei were recorded using a Leica Orthoplan (Milton Keynes, Bucks, UK) microscope equipped with a Ploempak epifluorescence module and a full turret of high N.A. Plan-APO fluorite lenses. 


\section{Detection of Transcript Levels in Bovine Oocytes}

The objective was to investigate the differences in transcript levels, if any, in oocytes matured under four different culture conditions: 1) T199+NCS, 2) cSOFM+NCS, 3) cSOFMaa, or 4) cSOFM. All the media were supplemented with gonadotropins (FSH, LH) and estradiol-17 $\beta$ as described above.

\section{RNA Isolation and Reverse Transcription (RT)}

Three replicate polymerase chain reaction (PCR) experiments were conducted for all genes of interest using oocytes collected from all 15 experimental replicates as described for experiment 1. Lysed pools of matured oocytes from each treatment were stored at $-70^{\circ} \mathrm{C}$ until all replicates were ready for simultaneous RNA isolation and RT. Likewise, the PCRs for all three replicates were performed simultaneously in order to minimize interexperimental variation. RNA was isolated from pooled oocytes as described previously [31,32]. Briefly, cumulus-denuded oocytes washed with serum-free handling medium were transferred in a minimum volume $(<1 \mu \mathrm{l})$ to a $0.5-\mathrm{ml}$ tube to which $10 \mu$ l of lysis buffer ( $4 \mathrm{M}$ guanidine thiocyanate, $0.1 \mathrm{M}$ Tris, $\mathrm{pH} 7.4,1 \mathrm{mM} \beta$-mercaptoethanol) was added; they were then frozen at $-70^{\circ} \mathrm{C}$. In this state, lysed embryos are stable for at least $1 \mathrm{yr}$. At the time of thawing, $0.1 \mathrm{pg}$ of rabbit globin mRNA (Gibco BRL), in a 1- to 2- $\mu$ l volume, was added per embryo and mixed by pipetting. For each sample, a $2 \times 2$-mm square of Hybond-messenger affinity paper (mAP; Amersham International, Buckinghamshire, UK) was cut and pre-wet with $0.5 \mathrm{M} \mathrm{NaCl}$ before being soaked in the lysed sample for 2-3 h at room temperature to allow for binding of poly $(\mathrm{A})^{+}$RNA. Each unabsorbed lysate was pipetted onto its respective mAP square supported on Whatman 1 filter paper (Whatman International Ltd, Springfield Mill, UK) on parafilm. The mAP squares were then individually transferred into separate $0.5-\mathrm{ml}$ tubes and washed by gentle inversion with $200-\mu 1$ volumes of $0.5 \mathrm{M} \mathrm{NaCl}-0.1 \mathrm{M}$ Tris (3 times), $0.5 \mathrm{M} \mathrm{NaCl}$ (3 times), and $70 \%$ ethanol ( 2 times). Poly (A) ${ }^{+}$RNA was eluted from each mAP square in fresh tubes in $11 \mu \mathrm{l}$ of sterile $\mathrm{H}_{2} \mathrm{O}$ containing $0.5 \mu \mathrm{g}$ oligo(dT) ${ }_{12-18}$ (Gibco BRL) by incubation at $70^{\circ} \mathrm{C}$ for $10 \mathrm{~min}$, followed by cooling on ice for 5 min. RT reactions were in a final volume of $20 \mu \mathrm{l}$ consisting of $50 \mathrm{mM}$ Tris- $\mathrm{HCl}(\mathrm{pH} 8.3), 75 \mathrm{mM} \mathrm{KCl}, 3 \mathrm{mM}$ $\mathrm{MgCl}_{2}, 10 \mathrm{mM}$ dithiothreitol, $750 \mu \mathrm{M}$ dNTPs, and 300 units of Superscript RNase $\mathrm{H}^{-}$(Gibco BRL) for 90 min at $43^{\circ} \mathrm{C}$. Reactions were terminated by $5 \mathrm{~min}$ at $95^{\circ} \mathrm{C}$ and then placed on ice. Reverse-transcribed cDNA was either used directly for PCR or stored at $-20^{\circ} \mathrm{C}$. As a negative control for RNA isolation and RT, a blank mAP square was carried along with samples during the procedure.

\section{PCR}

Experiments were conducted to contrast relative levels of transcripts encoding five marker genes including $\mathrm{Na}^{+} /$ $\mathrm{K}^{+}$ATPase $\alpha-1$ isoform, copper/zinc superoxide dismutase $(\mathrm{Cu} / \mathrm{Zn} \mathrm{SOD})$, basic fibroblast growth factor (bFGF), and cyclins $\mathrm{A}$ and $\mathrm{B}$. Oligodeoxynucleotide primers for $\mathrm{Na}^{+} /$ $\mathrm{K}^{+}$ATPase $\alpha-1$ were (5' primer) $5^{\prime}$-ACCTGTTGGGCATCCGAGAGAC-3' and ( $3^{\prime}$ primer) $5^{\prime}$-AGGGGAAGGCACAGAACCACCA-3'. These primers amplify a 336-base pair (bp) product from bovine cDNA [33]. Primers for bFGF were (5' primer) 5' -TACAACTTCAAGCAGAAGAG$3^{\prime}$ and ( $3^{\prime}$ primer) 5'-CAGCTCTTAGCAGACATTGG-3'.
These primers amplify a 282-bp product from bovine cDNA [34]. Primers for $\mathrm{Cu} / \mathrm{Zn}$ SOD were $\left(5^{\prime}\right.$ primer) $5^{\prime}$ AAGGCCGTGTGCGTGCTGAA-3' and ( $3^{\prime}$ primer) $5^{\prime}$ CAGGTCTCCAACATGCCTCT-3'. These primers amplify a 246-bp product from bovine cDNA [35]. Primers for cyclin A were $\left(5^{\prime}\right.$ primer) 5'-GTACCAGACTACCATGAGGAC-3' and (3' primer) 5'-TCCTGTGACTGTGTAGAGTGC-3'. These primers amplify a 585-bp product from bovine cDNA. Primers for cyclin B were ( $5^{\prime}$ primer) 5'ATGTGGATGCAGAAGACGGAG-3' and (3' primer) 5'-CCGCTGCAATCTGAGAAGGAG-3'. These primers amplify a 576-bp product from bovine cDNA. Primers for $\alpha$-globin were (5' primer) 5'-GCAGCCACGGTGGCGAGTAT- $3^{\prime}$ and (3' primer) 5'-GTGGGACAGGAGCTTGAAAT-3'. These primers amplify a $257-$ bp product [31].

PCRs were performed in $50 \mu \mathrm{l}$ of single-strength GeneAmp PCR buffer II (10 mM Tris-HCl, pH 8.3, $50 \mathrm{mM}$ $\mathrm{KCl}$; Perkin-Elmer, Canada Ltd, Mississauga, ON, Canada) containing $200 \mu \mathrm{M}$ dNTPs (Gibco BRL); 1 unit of AmpliTaq Gold DNA polymerase (Perkin-Elmer); $1 \mu \mathrm{M}$ (for $\mathrm{Na}^{+} / \mathrm{K}^{+}$ATPase $\alpha-1$ and $\alpha$-globin) or $2 \mu \mathrm{M}$ (for $\mathrm{Cu}$ / $\mathrm{ZnSOD}, \mathrm{bFGF}$, and cyclins $\mathrm{A}$ and $\mathrm{B}$ ) of each of the appropriate $3^{\prime}$ and $5^{\prime}$ gene-specific primers; $1 \mathrm{mM}$ (for $\mathrm{Na}^{+} / \mathrm{K}^{+}$ ATPase $\alpha-1$ and $\mathrm{Cu} / \mathrm{ZnSOD}), 1.25 \mathrm{mM}$ ( $\alpha$-globin), $2 \mathrm{mM}$ (bFGF), or $2.5 \mathrm{mM}$ (cyclins $\mathrm{A}$ and $\mathrm{B}$ ) $\mathrm{MgCl}_{2}$; and a volume of the RT reaction equivalent to 2 oocytes from the pools of reverse-transcribed oocytes. Reactions were cycled in either a Perkin-Elmer GeneAmp 2400 thermal cycler (bFGF; reactions not overlaid with oil), or a Perkin-Elmer Cetus 480 thermal cycler $\left(\mathrm{Na}^{+} / \mathrm{K}^{+}\right.$ATPase $\alpha-1$ and cyclins $\mathrm{A}$ and $\mathrm{B}$; reactions overlaid with light liquid paraffin oil $[\mathrm{BDH}])$, or a Thermolyne Amplitron (VWR Canlab, Mississauga, $\mathrm{ON}$, Canada) thermal cycler $(\mathrm{Cu} / \mathrm{ZnSOD}$ and $\alpha$-globin; reactions overlaid with light liquid paraffin oil). The basic program for amplification of gene transcripts consisted of a $95^{\circ} \mathrm{C}$ soak for $10 \mathrm{~min}$ followed by a cycle program of $95^{\circ} \mathrm{C}$ for $1 \mathrm{~min}$, a transcript-specific annealing temperature $\left(60^{\circ} \mathrm{C}, 55^{\circ} \mathrm{C}, 58^{\circ} \mathrm{C}, 49^{\circ} \mathrm{C}\right.$, and $55^{\circ} \mathrm{C}$ for $\mathrm{Cu} / \mathrm{ZnSOD}$, bFGF $\mathrm{Na}^{+} / \mathrm{K}^{+}$ATPase $\alpha-1$, cyclins $\mathrm{A}$ and $\mathrm{B}$, and $\alpha$-globin, respectively) for $30 \mathrm{sec}$, and $72^{\circ} \mathrm{C}$ for $1 \mathrm{~min}$. Extension was conducted at $72^{\circ} \mathrm{C}$ for $10 \mathrm{~min}$. Each transcript was amplified for a number of cycles at which the amplicon was accumulating exponentially (34 for $\alpha$-globin, 41 for bFGF, 42 for $\mathrm{Na}^{+} / \mathrm{K}^{+}$ATPase $\alpha-1$, and 45 for $\mathrm{Cu} / \mathrm{ZnSOD}$ and cyclins $\mathrm{A}$ and $\mathrm{B})$. The optimal cycle number for each transcript was established by running a linear cycle series with 2-cycle increments. The identity of each PCR product was confirmed by sequence analysis.

RT-PCR products were visualized by separation on $2 \%$ agarose gels in single-strength TAE buffer $(40 \mathrm{mM}$ Tris acetate, $1 \mathrm{mM}$ EDTA) run at $100 \mathrm{~V}$ for $50 \mathrm{~min}$, with all three replicates run on the same gel. Gels were stained for $30 \mathrm{~min}$ at room temperature with $0.5 \mu \mathrm{g} / \mathrm{ml}$ ethidium bromide in single-strength TAE buffer, followed by destaining in deionized water for 5-10 min. The products were imaged using an ImageMaster VDS (Pharmacia Biotech, Baie d'Urfe, PQ, Canada). The fluorescence of ethidium bromide-stained DNA, as determined by quantitation image analysis, is proportional to the amount of DNA in each band and is independent of size and sequence of the DNA. The relative band intensities were determined from images imported into a personal computer using the Image Capture Kit and ImageMaster VDS software (Pharmacia Biotech).

\section{Data Calculations}

The absolute integrated optical density (IOD), i.e., the volume of the gel band, was determined for all the ampli- 


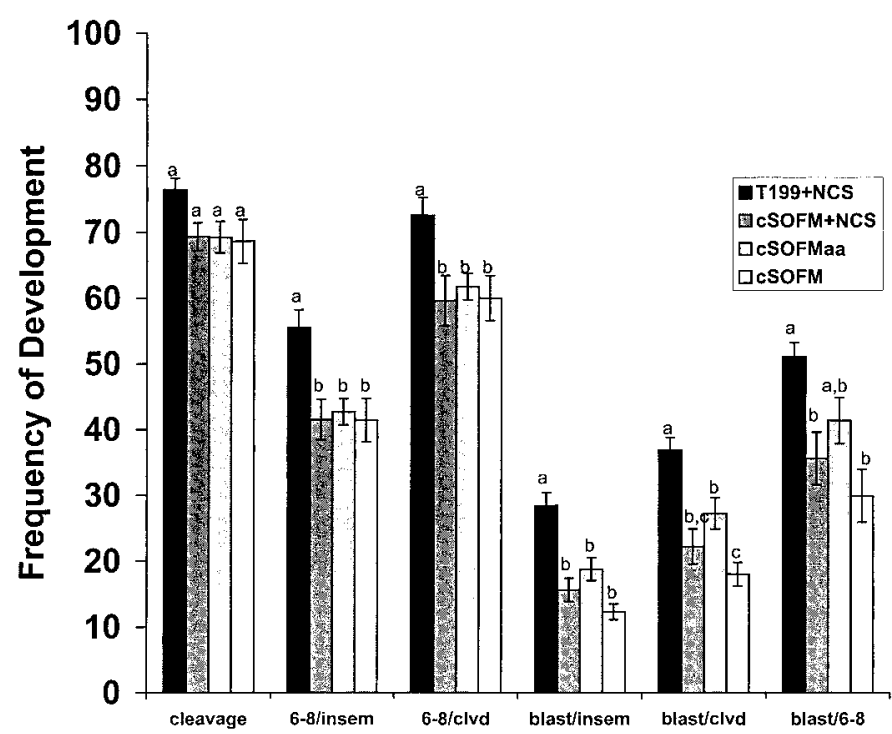

FIG. 1. Influence of serum and amino acid supplementation of oocyte maturation media on blastocyst development: frequency of cleavage, 6 to 8-cell-stage embryos (over inseminated oocytes [6-8/insem] and cleaved embryos [6-8/clvd]), and blastocysts (over inseminated oocytes [blast/insem], cleaved embryos [blast/clvd], and 6- to 8-cell embryos [blast/6-8]) displayed by oocytes matured in 1) T199+NCS; 2) CSOFM+NCS; 3) cSOFMaa; and 4) cSOFM supplemented with gonadotropins and estradiol-17 $\beta$. Cleavage did not vary among treatments. Oocyte maturation in T199+NCS resulted in a significant enhancement of development to the 6- to 8-cell and blastocyst stages. However, the proportion of 6- to 8-cell embryos that progressed to the blastocyst stage did not vary between the T199+NCS and CSOFMaa treatments. Values with different superscript letters are significantly different $(P<0.05)$.

cons including the 400-bp band of a 100-bp DNA ladder ( $5 \mu \mathrm{g}$; Gibco BRL) run on each gel. The IOD value for the 400-bp band on the gel for each specific transcript was equated with the IOD value for the 400-bp band on the $\alpha$ globin gel to establish a conversion factor. This was used to calculate the IOD values for each culture group in the three replicates relative to the exogenous $\alpha$-globin standard. Abundance ratios of the IODs for the specific gene transcripts relative to the comparable IODs for the $\alpha$-globin were then determined.

\section{Statistical Analysis}

Data for all experiments were analyzed using the SigmaStat (Jandel Scientific, San Rafael, CA) software package. One-way ANOVA, followed by pair-wise multiple comparisons (Bonferroni's method), was used for analysis of differences in the means for two or more populations. Differences of $P \leq 0.05$ were considered significant.

\section{RESULTS}

\section{Experiment 1}

The first experiment was an examination of the influences of serum, amino acids, and culture media (TCM199 vs. cSOFM), employed for bovine oocyte maturation, on development to the blastocyst stage. No significant differences in cleavage were observed among the four oocyte maturation treatment groups $(P<0.05$; Fig. 1). Development to the 6- to 8-cell stage was significantly greater $(P$ $<0.05)$ in the T199+NCS treatment, with no difference in this parameter among the remaining three treatments (Fig. $1)$. Blastocyst development was significantly greater $(P<$

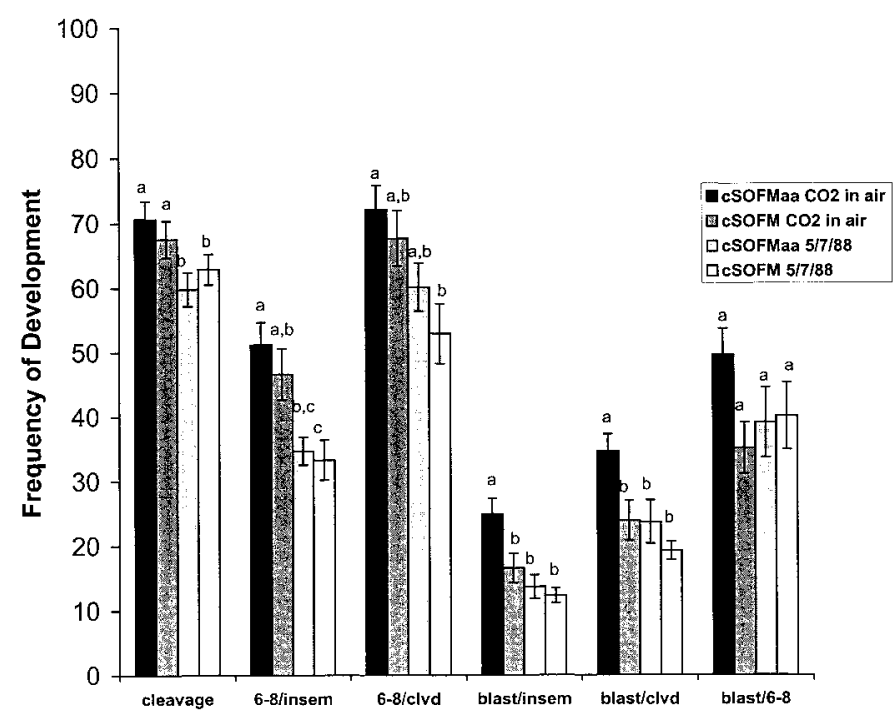

FIG. 2. Influence of culture atmosphere and amino acids during oocyte maturation on blastocyst development displayed by oocytes matured in cSOFMaa or CSOFM supplemented with gonadotropins and estradiol$17 \beta$. Half of the COCs (including both + and - amino acid groups) were matured under a $5 \% \mathrm{CO}_{2}, 7 \% \mathrm{O}_{2}, 88 \% \mathrm{O}_{2}$ culture atmosphere and half under a $5 \% \mathrm{CO}_{2}$-in-air culture atmosphere. See Figure 1 legend for a full description of the groups. Cleavage was significantly greater in the $5 \%$ $\mathrm{CO}_{2}$-in-air culture atmosphere and was not influenced by amino acid supplementation. Development to the 6- to 8-cell and blastocyst stages was significantly enhanced in the amino acid-supplemented $5 \% \mathrm{CO}_{2}$-inair culture atmosphere. The proportion of 6- to 8-cell-stage embryos progressing to the blastocyst stage did not vary significantly among treatments. Values with different superscript letters are significantly different $(P<0.05)$.

0.05) in the T199+NCS oocyte maturation treatment group than for the other treatments (Fig. 1). Blastocyst formation expressed over the proportion of cleaved embryos (blast/ clvd), however, was significantly greater $(P<0.05)$ in the cSOFMaa oocyte maturation treatment than for the cSOFM maturation treatment (Fig. 1). The T199+NCS treatment also displayed a significant increase $(P<0.05)$ in the proportion of 6- to 8-cell embryos that developed to the blastocyst stage over that with the cSOFM+NCS and cSOFM treatment groups (Fig. 1). Interestingly, however, the proportion of 6- to 8-cell-stage embryos progressing to the blastocyst stage did not vary significantly between the T199+NCS and cSOFMaa treatment groups (Fig. 1).

\section{Experiment 2}

The next investigation concerned the influence of culture atmosphere during bovine oocyte maturation in vitro on development to the blastocyst stage. Oocyte maturation under a $5 \% \mathrm{CO}_{2}$-in-air atmosphere supported significantly greater $(P<0.05)$ cleavage frequencies than for oocytes matured under a $5 \% \mathrm{CO}_{2}, 7 \% \mathrm{O}_{2}, 88 \% \mathrm{~N}_{2}(5 / 7 / 88)$ culture atmosphere (Fig. 2). Amino acid supplementation of oocyte maturation media did not significantly influence cleavage. Development to the 6- to 8-cell stage did not vary significantly between the two $5 \% \mathrm{CO}_{2}$-in-air treatments but was significantly greater $(P<0.05)$ in both of these groups than in the cSOFM 5/7/88 group (Fig. 2). Development to the blastocyst stage was significantly higher $(P<0.05)$ in the cSOFMaa $5 \% \mathrm{CO}_{2}$-in-air oocyte maturation group than in the other treatments (Fig. 2). No significant difference in blastocyst formation frequency was observed in the cSOFM $5 \% \mathrm{CO}_{2}$-in-air and the two 5/7/88 oocyte maturation treat- 


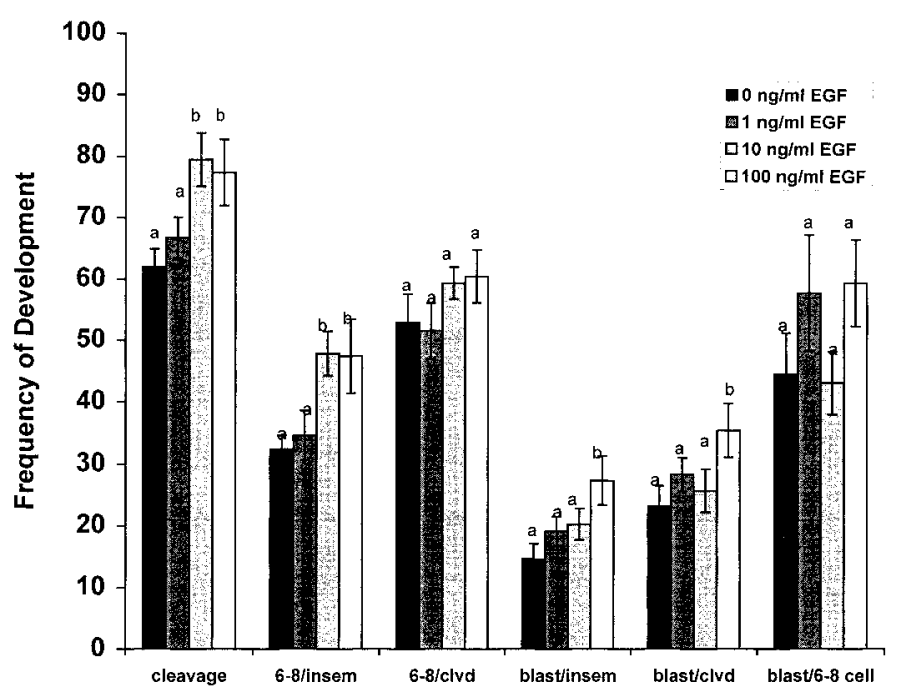

FIG. 3. Influence of EGF during oocyte maturation on blastocyst development displayed by oocytes matured in $0,1,10$, and $100 \mathrm{ng} / \mathrm{ml}$ of murine EGF-supplemented cSOFMaa. See Figure 1 legend for a full description of the groups. Cleavage and development to the 6- to 8-cell and blastocyst stages varied significantly among the treatment groups in a concentration-dependent manner. The proportion of 6- to 8-cell embryos that progressed to the blastocyst stage did not vary among the four treatments. Values with different superscript letters are significantly different $(P<$ 0.05).

ments. The proportion of 6- to 8-cell-stage embryos progressing to the blastocyst stage did not vary significantly among the oocyte maturation treatments (Fig. 2).

\section{Experiment 3}

The influence of EGF-supplemented cSOFMaa oocyte maturation medium on development to the blastocyst stage was investigated next. We first examined influences on cumulus cell expansion. EGF stimulated cumulus cell expansion in a concentration-dependent manner with the greatest amount of expansion occurring in the $100 \mathrm{ng} / \mathrm{ml}$ EGF treatment (data not shown). However, the proportion of fully expanded COCs observed even at this EGF concentration was not as extensive as we normally observe with FSHsupplemented oocyte maturation media. EGF stimulated a concentration-dependent increase in cleavage and 6- to 8cell-stage embryos, as both the $10 \mathrm{ng} / \mathrm{ml}$ and $100 \mathrm{ng} / \mathrm{ml}$ treatments displayed a significant increase $(P<0.05)$ in these parameters over that for the control and $1 \mathrm{ng} / \mathrm{ml}$ treatment (Fig. 3). Interestingly, the proportion of 6- to 8-cell-

TABLE 1. Blastocyst total cell number and apoptosis following oocyte maturation in TCM-199+NCS, cSOFM+NCS, cSOFMaa, or cSOFM (means \pm SEM).

\begin{tabular}{lcccr}
\hline Treatment* & $\mathrm{n}$ & Total cell no. & $\begin{array}{c}\text { Apoptosis } \\
\text { (cell no.) }\end{array}$ & $\begin{array}{c}\text { Apoptosis } \\
\text { (\% of total } \\
\text { cells) }\end{array}$ \\
\hline TCM-199+NCS & 34 & $168.2 \pm 6.1^{\mathrm{a}}$ & $16.3 \pm 1.7$ & $9.5 \pm 0.8$ \\
CSOFM+NCS & 34 & $138.2 \pm 7.0^{\mathrm{b}}$ & $11.8 \pm 0.9$ & $9.1 \pm 0.8$ \\
CSOFMaa & 34 & $157.6 \pm 7.1^{\mathrm{a}, \mathrm{b}}$ & $13.4 \pm 1.5$ & $8.5 \pm 0.9$ \\
CSOFM & 34 & $132.8 \pm 7.7^{\mathrm{b}}$ & $16.3 \pm 2.1$ & $13.0 \pm 1.6$ \\
\hline
\end{tabular}

* All cumulus-oocyte-complexes were matured in one of the four treatment groups under a $5 \% \mathrm{CO}_{2}$ in air at $39^{\circ} \mathrm{C}$ culture atmosphere; inseminated oocytes from each oocyte maturation treatment were cultured to the blastocyst stage in cSOFMaa medium under a $5 \% \mathrm{CO}_{2} / 7 \% \mathrm{O}_{2} / 88 \%$ $\mathrm{N}_{2}$ culture atmosphere at $39^{\circ} \mathrm{C}$.

a,b $P<0.05$ for treatments with different superscripts.
TABLE 2. Blastocyst total cell number and apoptosis following oocyte maturation in CSOFMaa or CSOFM under $5 \% \mathrm{CO}_{2}$ in air and $5 \% \mathrm{CO}_{2} /$ $7 \% \mathrm{O}_{2} / 88 \% \mathrm{~N}_{2}$ culture atmospheres (means $\pm \mathrm{SEM}$ ).

\begin{tabular}{|c|c|c|c|c|}
\hline Treatment* & $\mathrm{n}$ & Total cell no. & $\begin{array}{l}\text { Apoptosis } \\
\text { (cell no.) }\end{array}$ & $\begin{array}{c}\text { Apoptosis } \\
\text { (\% of total } \\
\text { cells) }\end{array}$ \\
\hline \multicolumn{5}{|l|}{ CSOFMaа } \\
\hline $\begin{array}{l}5 \% \mathrm{CO}_{2} \\
\text { CSOFM }\end{array}$ & 38 & $133.8 \pm 8.0$ & $13.2 \pm 1.1$ & $10.4 \pm 0.8$ \\
\hline $5 \% \mathrm{CO}_{2}$ & 38 & $129.0 \pm 6.0$ & $12.1 \pm 1.1$ & $9.4 \pm 0.8$ \\
\hline $\begin{array}{l}\text { CSOFMaa } \\
5 \% \mathrm{CO}_{2}, 7 \% \mathrm{O}_{2} \\
88 \% \mathrm{~N}_{2}\end{array}$ & 38 & $125.6 \pm 7.5$ & $10.9 \pm 1.0$ & 0.7 \\
\hline CSOFM & & & & \\
\hline $\begin{array}{l}5 \% \mathrm{CO}_{2}, 7 \% \mathrm{O}_{2} \\
88 \% \mathrm{~N}_{2}\end{array}$ & 38 & $131.5 \pm 7.9$ & $9.6 \pm 0.9$ & $7.7 \pm 0.6$ \\
\hline
\end{tabular}

* All inseminated oocytes from each oocyte maturation treatment were cultured to the blastocyst stage in cSOFMaa medium under a $5 \% \mathrm{CO}_{2} /$ $7 \% \mathrm{O}_{2} / 88 \% \mathrm{~N}_{2}$ culture atmosphere at $39^{\circ} \mathrm{C}$.

stage embryos over cleaved embryos (6- to 8-cell/clvd) did not vary significantly among the four treatments (Fig. 3). There was a trend for a dose-dependent increase in blastocyst formation, but only in the $100 \mathrm{ng} / \mathrm{ml}$ EGF treatment, which displayed a significant $(P<0.05)$ increase in blastocyst formation (Fig. 3). The proportion of 6- to 8-cellstage embryos that progressed to the blastocyst stage did not vary significantly among the four treatments (Fig. 3).

\section{Blastocyst Total Cell Numbers and Apoptosis}

In experiment 1, blastocyst total cell number was significantly greater $(P<0.05)$ in the T199+NCS treatment than in the cSOFM+NCS and cSOFM treatment groups (Table 1). However, the total blastocyst cell number did not vary significantly between the T199+NCS and cSOFMaa treatments (Table 1). The incidence of apoptotic cells did not vary significantly among these four treatment groups (Table 1). No significant differences in blastocyst total cell number or number of apoptotic cells were observed in blastocysts derived from the four oocyte maturation treatment groups in the second experiment (Table 2). Likewise, EGF supplementation of oocyte maturation media did not significantly influence blastocyst cell number or apoptosis (Table 3). Day 8 blastocyst total cell numbers ranged from 53 to 317 cells from all three experiments. Representative images of labeled blastocysts for total cell counts and measurement of apoptosis are displayed in Figure 4.

TABLE 3. Blastocyst total cell number and apoptosis following oocyte maturation in cSOFMaa supplemented with either 1,10 , or $100 \mathrm{ng} / \mathrm{ml}$ of EGF (means \pm SEM).

\begin{tabular}{lcccc}
\hline Treatment* & $\mathrm{n}$ & Total cell no. & $\begin{array}{c}\text { Apoptosis } \\
\text { (cell no.) }\end{array}$ & $\begin{array}{c}\text { Apoptosis } \\
\text { (\% of total } \\
\text { cells) }\end{array}$ \\
\hline Control & 11 & $141.3 \pm 17.3$ & $54.3 \pm 14.2$ & $34.5 \pm 6.2$ \\
$1 \mathrm{ng} / \mathrm{ml} \mathrm{EGF}$ & 22 & $147.3 \pm 12.6$ & $54.5 \pm 11.2$ & $39.5 \pm 6.8$ \\
$10 \mathrm{ng} / \mathrm{ml} \mathrm{EGF}$ & 23 & $149.3 \pm 10.1$ & $36.7 \pm 3.7$ & $25.5 \pm 2.3$ \\
$100 \mathrm{ng} / \mathrm{ml} \mathrm{EGF}$ & 29 & $158.3 \pm 11.8$ & $40.3 \pm 7.6$ & $24.6 \pm 3.3$ \\
\hline
\end{tabular}

* All cumulus-oocyte-complexes were matured in one of the four treatment groups under a $5 \% \mathrm{CO}_{2}$ in air at $39^{\circ} \mathrm{C}$ culture atmosphere; inseminated oocytes from each oocyte maturation treatment were cultured to the blastocyst stage in cSOFMaa medium under a $5 \% \mathrm{CO}_{2} / 7 \% \mathrm{O}_{2} / 88 \%$ $\mathrm{N}_{2}$ culture atmosphere at $39^{\circ} \mathrm{C}$. 


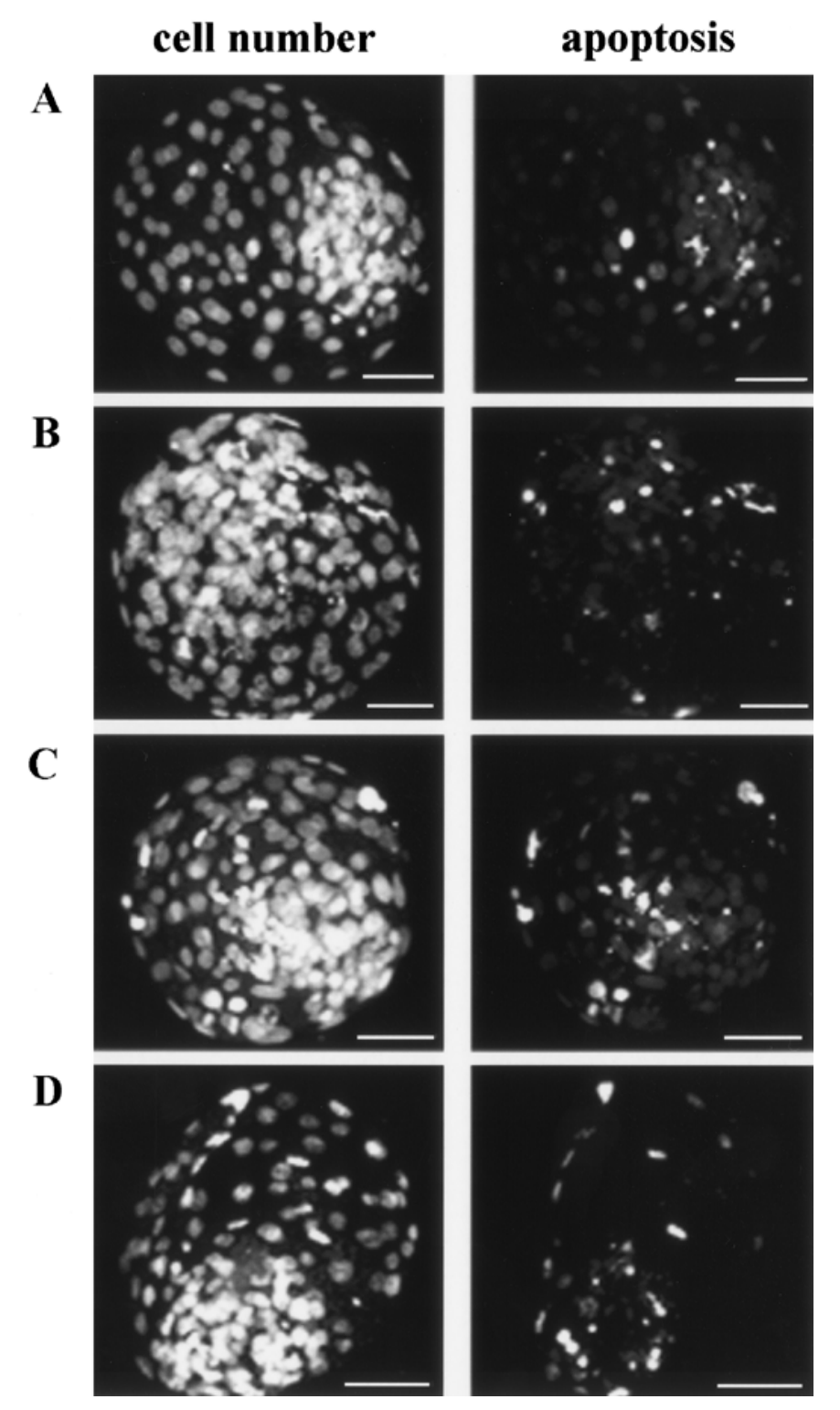

FIG. 4. Representative images of blastocyst total cell number and apoptosis. Shown are blastocysts consisting of A) 161 total cells and 21 apoptotic cells produced from the T199+NCS oocyte maturation treatment; B) 198 total cells and 16 apoptotic cells produced from the cSOFM+NCS oocyte maturation treatment; C) 177 cells and 16 apoptotic cells produced from the cSOFMaa oocyte maturation treatment; D) 148 cells and 25 apoptotic cells produced from the cSOFM treatment. Bars $=50 \mu \mathrm{M}$.

\section{Oocyte Transcript Levels}

The abundance of each specific gene transcript was expressed relative to an exogenously supplied $\alpha$-globin mRNA standard as described above. Figure 5 displays the ethidium bromide-stained gels for each oocyte transcript and experimental replicate. The mean relative mRNA abundance for the five specific transcripts is displayed in Figure 6 . The relative abundance of transcripts encoding the $\mathrm{Na}^{+} /$ $\mathrm{K}^{+}$ATPase $\alpha-1$ isoform did not vary significantly between the T199+NCS, cSOFM+NCS, and cSOFMaa treatments; but all three of these treatments displayed a significantly higher $(P<0.05)$ relative abundance of this gene product than in oocytes matured in the cSOFM treatment (Figs. 5 and 6). An identical outcome was observed for transcripts encoding cyclin A (Figs. 5 and 6). No significant differences in the relative abundance of transcripts encoding $\mathrm{Cu} /$

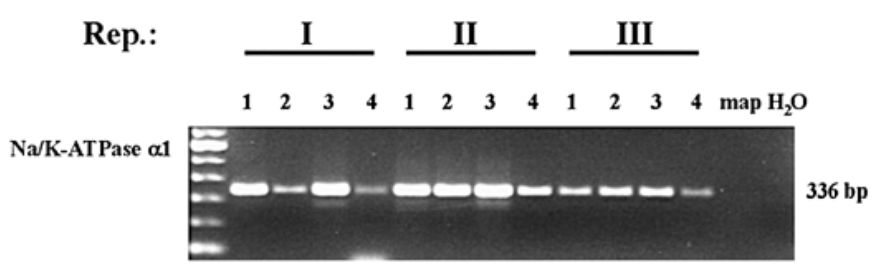

bFGF

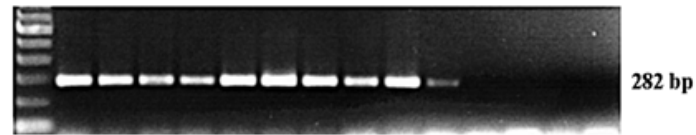

Cu/Zn SOD

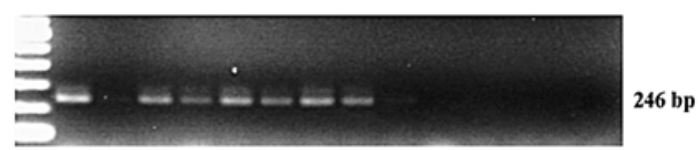

Cyclin A

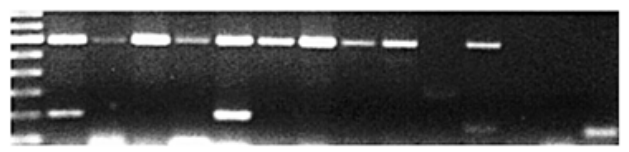

Cyclin B

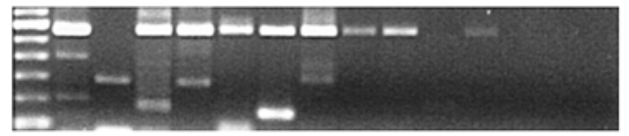

$\alpha$-globin

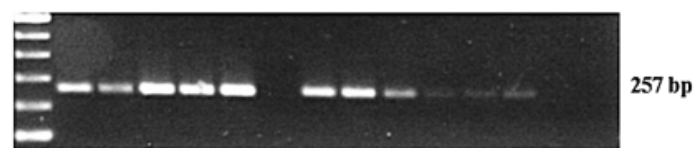

FIG. 5. RT-PCR analysis of oocyte transcripts. Experiments were conducted to contrast relative levels of transcripts encoding five marker genes including $\mathrm{Na}^{+} / \mathrm{K}^{+}$ATPase $\alpha-1$ isoform, bFGF, Cu/ZnSOD, cyclins A and $B$, and exogenously supplied $\alpha$-globin in oocytes matured in 1) T199+NCS, 2) cSOFM+NCS, 3) cSOFMaa, and 4) cSOFM. Ethidium bromide-stained gels displaying the amplified product of each transcript in all three experimental replicates. map, a blank mAP paper control; $\mathrm{H}_{2} \mathrm{O}$, a minus cDNA blank control. The expected sizes of each cDNA amplicon are displayed.

$\mathrm{Zn}$ SOD, cyclin B, and bFGF were observed among the oocyte maturation treatment groups. There was, however, a noteworthy trend toward a lower relative abundance of transcripts encoding bFGF within the serum-free treatments (Fig. 5).

\section{DISCUSSION}

This study has contrasted the influences of bovine oocyte maturation environments on blastocyst formation frequency, total cell number, apoptosis, and oocyte transcript levels. Our findings indicate not only that cSOFMaa medium is an effective base medium for embryo culture $[14,15,18,29,36]$ but also that it can be effectively employed as a base medium for oocyte maturation. We employed for the first time an assessment of blastocyst total cell number and apoptosis to examine influences of oocyte maturation environments on bovine blastocyst development. The results demonstrate that blastocysts derived from in vitro maturation, fertilization, and embryo culture protocols undergo apoptosis. However, apoptotic levels are not greatly influenced by the oocyte maturation environment. Amino acid supplementation of oocyte maturation media was associated with enhanced developmental frequencies, increased blastocyst cell number, and elevated oocyte maternal mRNA levels. Oocyte maturation with cSOFMaa medium resulted in blastocyst cell numbers comparable to 


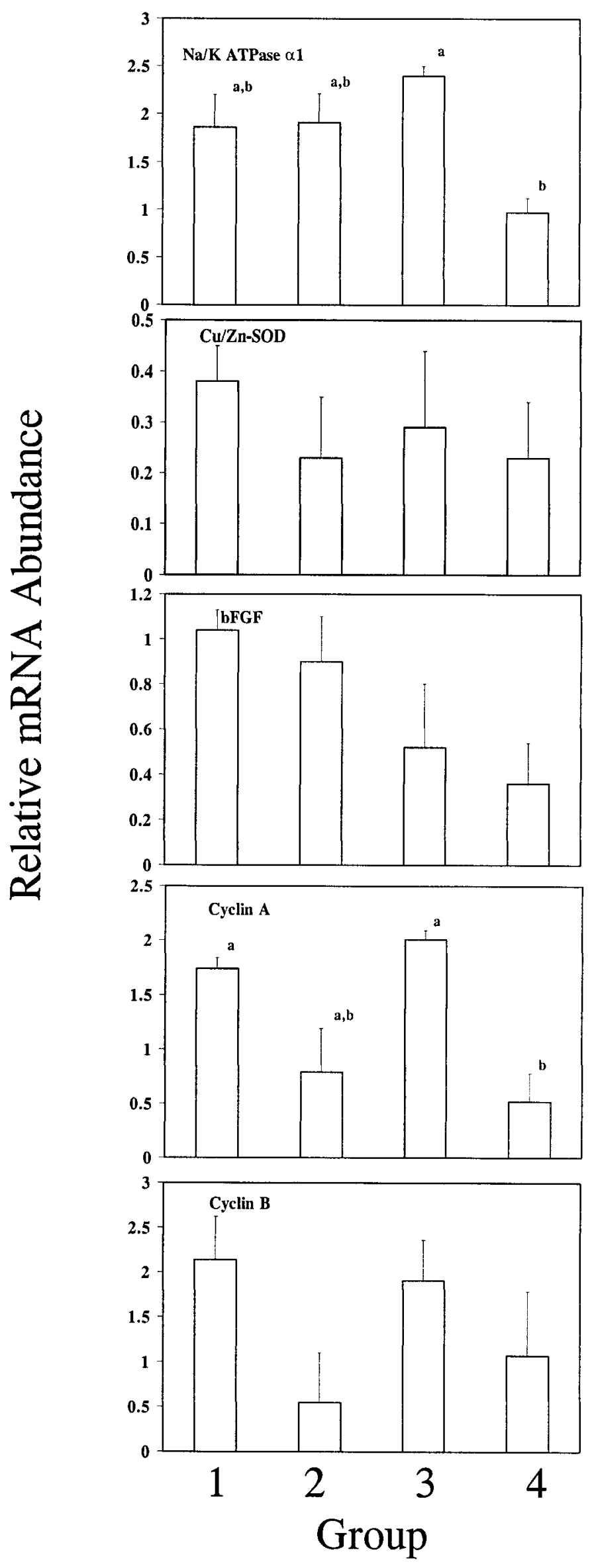

those observed when TCM199+NCS is employed. Blastocyst development was reduced after oocyte maturation under a $5 \% \mathrm{CO}_{2}, 7 \% \mathrm{O}_{2}, 88 \% \mathrm{~N}_{2}$ culture atmosphere. EGF supplementation of oocyte maturation medium resulted in a concentration-dependent increase in blastocyst development but did not influence blastocyst total cell number or apoptosis.

The development of bovine oocyte maturation and embryo culture systems occurred in the mid- to late 1980s and initially involved serum-supplemented media and embryo coculture methods $[9-14,37]$. These initial systems were critical for advancing research on early mammalian development and also for applying assisted-reproductive technologies to domestic species. Although their importance is beyond question, it is also certain that the requirement for serum supplementation and embryo coculture restricted advancements in our understanding of embryo physiology and the regulatory events that oversee early development $[18,38]$. Concerns have been raised regarding interpretation of results generated from embryos exposed to undefined and suboptimal culture conditions [2-4,8,39,40]. For these reasons, it was important that effective fully defined systems be developed [7,15-18,29,36].

The complete removal of serum from culture protocols has been challenging, and was first applied to embryo culture media. Transitional stages from serum supplementation have included replacement with BSA and, most recently, the addition of PVA and amino acids [15,16,21-25,36]. Amino acids may serve as osmolytes, energy substrates, $\mathrm{pH}$ regulators, and chelators of heavy metals and as precursors for protein synthesis $[18,41,42]$. Their addition to SOFM and KSOM (potassium simplex optimized medium) media effectively supports development of ovine, bovine, and murine early embryos in the absence of serum $[15,16,21-$ $25,36,43]$.

Research efforts have recently focused on characterizing serum-free bovine oocyte maturation media $[15,18,21-25]$. These studies have reported successful development of bovine embryos to the blastocyst stage following serum-free oocyte maturation using for the most part serum-free TCM199 as a base oocyte maturation medium [15,18,2125]. There is little specific rationale for employing TCM199 for either oocyte maturation or embryo culture. Although there is little doubt regarding the current effectiveness of this medium for these purposes, TCM199 is a complex medium that was not specifically designed for embryo culture and is not likely formulated with the ideal levels of components required to support early mammalian development. Furthermore, since TCM199 is a commercial medium, it is very difficult to modify individual components to examine specific effects on development. For these reasons we investigated the use of cSOFMaa medium for bovine oocyte maturation. It can be argued that cSOFMaa medium is also not completely optimized for oocyte maturation or embryo culture. Since, however, it is a completely defined simple

FIG. 6. Variation in oocyte marker gene transcripts. The relative abundance of each marker gene transcript for oocytes cultured in 1) T199+NCS, 2) cSOFM+NCS, 3) cSOFMaa, and 4) cSOFM is presented. Transcripts encoding $\mathrm{Na}^{+} / \mathrm{K}^{+}$ATPase $\alpha-1$ isoform and cyclin B were significantly reduced in the amino acid-free cSOFM. Transcripts encoding $\mathrm{Cu} / \mathrm{ZnSOD}, \mathrm{bFGF}$, and cyclin A were not present at significantly different levels among the oocyte maturation treatments. However, there was a trend for transcripts encoding bFGF to be reduced in the serum-free culture treatments. Values with different superscript letters are significantly different $(P<0.05)$. 
medium, it can be easily modified to investigate the effects of specific components. SOFM was designed from concentrations of salts and energy metabolites found in sheep oviductal fluid [44], and this medium is "the standard" for ovine embryo culture. SOFM medium has been used effectively to support bovine development in vitro $[15,16,18]$. Keskintepe et al. [15,16] observed an important benefit from the addition of citrate to SOFM media. Citrate may act as a regulator of fatty acid synthesis, ion chelation, and solute transport, and its addition to SOFM in combination with NEA is beneficial for obtaining maximal blastocyst formation frequencies with this medium $[15,16]$. For several years now we have employed this base medium with phosphate removed and glucose levels reduced to support bovine embryo development in vitro. This medium consistently supports high frequencies of development of bovine embryos to the blastocyst stage in vitro. For these reasons we proposed that cSOFMaa medium would be a useful base medium for oocyte maturation studies as well. The results from this study certainly support this view.

The culture atmosphere plays a critical role during oocyte maturation and embryo culture. Tervit et al. [45] first reported a benefit of culture under reduced $\mathrm{O}_{2}\left(5 \% \mathrm{CO}_{2}\right.$, $5 \% \mathrm{O}_{2}, 90 \% \mathrm{~N}_{2}$ ) atmosphere, but this approach was not widely adopted for the culture of mammalian embryos from other species until it became apparent that reduced $\mathrm{O}_{2}$ atmospheres eliminated a requirement for embryo coculture with somatic cells and also increased blastocyst frequencies in all mammalian species tested including the mouse [15$17,29,44-49]$. This benefit may stem from a reduction in the deleterious effects of reactive oxygen species on early development. A 5\% $\mathrm{CO}_{2}$-in-air culture atmosphere is typically employed for the in vitro maturation of mammalian oocytes. Our study examined whether this culture atmosphere is optimal for bovine oocyte maturation. Blastocyst development was reduced following oocyte maturation under a $5 \% \mathrm{CO}_{2}, 7 \% \mathrm{O}_{2}, 88 \% \mathrm{~N}_{2}$ culture atmosphere. We would speculate that cumulus cell metabolism is adversely affected by exposure to reduced $\mathrm{O}_{2}$ culture atmospheres, and this impairs cumulus cell-oocyte interactions during oocyte maturation, thus reducing overall developmental potential. Cumulus cell expansion and attachment were markedly reduced in COCs matured under a reduced $\mathrm{O}_{2}$ culture atmosphere, and these observations support this hypothesis.

EGF positively influences oocyte maturation in a number of species, including cattle [50-59]. Its addition to serumfree TCM199 is sufficient to support high frequencies of bovine oocyte maturation and subsequent development to the blastocyst stage [50-53]. Its role, however, in regulating bovine blastocyst cell number or apoptosis after its addition to oocyte maturation medium has not been investigated. Our results clearly demonstrated an early influence of EGF on cumulus cell expansion and cleavage. Our results, however, do not support an influence of EGF during oocyte maturation on development of 6- to 8-cell-stage embryos to the blastocyst stage or on blastocyst cell number or apoptosis. This of course does not suggest that EGF does not serve as a regulator of blastocyst formation. However, EGF-mediated influences on oocyte maturation simply may not persist beyond these early cleavage stages. However, by increasing the proportion of cleaved embryos, EGF treatment during oocyte maturation indirectly promotes increased development to the blastocyst stage.

Programmed cell death, or apoptosis, has been detected at the blastocyst stage, in both the inner cell mass and trophectoderm, as a normal feature of murine development
[26,27]. We have now demonstrated that bovine blastocysts also display apoptosis. Although the role of cell death in the early embryo is unknown, it may involve the removal of cells with abnormal properties or inappropriate potential. There is evidence to suggest that certain "survival" factors, such as growth factors, produced by the embryo and maternal reproductive tract play a role in controlling apoptosis levels [26,27]. EGF receptor ligands have been linked to reduced apoptosis in murine blastocysts [26,27]. Although the addition of EGF to oocyte maturation medium did not influence blastocyst apoptosis, we would expect that treatment of bovine embryos with EGF or transforming growth factor- $\alpha$ would reduce bovine blastocyst apoptosis in a similar fashion. This outcome, however, awaits further experimentation. We believe that the majority of the apoptotic cells observed in our bovine blastocysts were located in the inner cell mass as opposed to the trophectoderm. This can be confirmed only by differential staining techniques, which are incompatible with the double-labeling procedure employed in this study. The level of apoptosis we observed is similar to that reported for murine embryos [26,27], and therefore we would predict that it represents an expected level of apoptosis for cultured blastocysts. The blastocyst total cell number values reported in the present study are in agreement with values for Day 8 bovine blastocysts reported for oocytes matured in TCM199+serum and then cultured in serum-supplemented medium [28]. We can conclude, therefore, that serum-free oocyte maturation and embryo culture environments do not result in reduced blastocyst cell numbers. A proven semiquantitative RT-PCR method was applied to examine relative variations in the levels of transcripts encoding five marker genes [31]. We chose $\mathrm{Na}^{+} / \mathrm{K}^{+}$ATPase $\alpha-1$ isoform, bFGF, Cu/ZnSOD, and cyclins $\mathrm{A}$ and $\mathrm{B}$ as genes of interest for the following reasons: 1 ) $\mathrm{Na}^{+} / \mathrm{K}^{+}$ATPase $\alpha-1$ isoform is an important housekeeping gene controlling plasma membrane ionic concentration gradients, and it facilitates the trophectoderm ion transport mechanisms that control blastocyst formation $[33,60]$; 2) bFGF is a maternally expressed growth factor gene, as transcripts encoding bFGF are reported in bovine and ovine embryos up to the 8- to 16-cell stage and are absent in blastocysts [34]; 3) $\mathrm{Cu} / \mathrm{ZnSOD}$ is an antioxidant gene, especially important in high oxygen concentration environments [35]; 4) cyclins A and B are important genes controlling cell cycle events and germinal vesicle breakdown [61]. Cyclin A controls the progression of the cell from $\mathrm{G} 1$ to $\mathrm{S}$ phase and peaks during the $\mathrm{S}$ phase. Cyclin $\mathrm{B}$ is an active mediator of meiotic progression, controlling the entry into and exit of the cell from the $M$ phase [61]. Our results have clearly demonstrated that oocyte maturation media can influence levels of oocyte transcripts. Furthermore, the greatest deficit was observed using the amino acid-free cSOFM medium. This medium also supported the lowest developmental frequencies. Therefore our studies have linked oocyte mRNA levels with the capacity of the oocyte, once fertilized, to develop to the blastocyst stage in vitro. These findings are supported by other studies that have examined influences of culture media on embryonic transcript levels $[39,40,62]$. The decreased relative levels of $\mathrm{Na}^{+} / \mathrm{K}^{+}$ATPase $\alpha-1$ isoform and cyclin A mRNAs observed in oocytes matured in amino acid-free cSOFM medium may reflect the acceleration of mechanisms that direct the degradation of maternal mRNAs prior to eventual activation of the embryonic genome [63-66]. In particular, it is possible that these mRNAs are subject to early deadenylation that would result in truncated poly(A)-tails and re- 
duced RT by oligo(dT) [63-66]. The precise cause of the observed reduction in transcript levels and their full functional significance await further experimentation. Our results demonstrate that oocyte culture media can influence transcript levels and that the use of serum-free amino acidsupplemented defined media for oocyte maturation maintains transcripts at levels observed in oocytes matured in serum-supplemented media.

The characterization of fully defined optimized culture conditions for preimplantation development in vitro is an obvious priority, especially when there is increasing evidence demonstrating negative consequences of culture in suboptimal environments on patterns of embryonic gene expression and, more dramatically, on fetal phenotype in animal models $[2-4,8,35,39,40]$. These points are of particular importance as the assisted-reproduction technology field prepares to adopt human in vitro oocyte maturation and embryo culture to the blastocyst stage as emerging advancements. Our results support the use of serum-free defined conditions for both oocyte maturation and embryo culture in vitro. These approaches will allow for studies aimed at defining the precise roles of hormonal and growth factor modulators in supporting early development and should result in the eventual characterization of optimal conditions for early mammalian embryo culture.

\section{ACKNOWLEDGMENTS}

We thank John Looye and the ABEL laboratories (University of Guelph) for assisting with ovary and oocyte collections and Drs. John Eppig, Randy Prather, and Barry Bavister (members of the NIH "culture club") for critically reviewing this manuscript.

\section{REFERENCES}

1. Heyner S. Applications of animal embryo culture research to human IVF and embryo transfer programs. In: Bavister BD (ed.), The Mammalian Preimplantation Embryo: Regulation of Growth and Differentiation In Vitro. New York: Plenum Press; 1987: 333-340.

2. Farin PW, Farin CE. Transfer of bovine embryos produced in vivo or in vitro: survival and fetal development. Biol Reprod 1995; 52:676682 .

3. Behboodi E, Anderson GB, BonDurant RH, Cargill SL, Kreuscher BR, Medrano JF, Murray JD. Birth of large calves that developed from in vitro-derived bovine embryos. Theriogenology 1995; 44:227-232.

4. Thompson JG, Gardner DK, Pugh PA, McMillan WH, Tervit HR. Lamb birth weight is affected by culture system utilized during in vitro pre-elongation development of ovine embryos. Biol Reprod $1995 ; 53: 1385-1391$

5. Chatot CL, Lewis JL, Torres I, Ziomek CA. Development of 1-cell embryos from different strains of mice in CZB medium. Biol Reprod 1990; 42:432-440.

6. Chatot CL, Ziomek CA, Bavister BD, Lewis JL, Torres I. An improved culture medium supports development of random-bred-cell mouse embryos in vitro. J Reprod Fertil 1989; 86:679-688.

7. Summers MC, Bhatnagar PR, Lawitts JA, Biggers JD. Fertilization in vitro of mouse ova from inbred and outbred strains: complete preimplantation embryonic development in glucose-supplemented KSOM. Biol Reprod 1995; 53:431-437.

8. Ho Y, Wigglesworth K, Eppig JJ, Schultz RM. Preimplantation development of mouse embryos in KSOM: augmentation by amino acids and analysis of gene expression. Mol Reprod Dev 1995; 41:232-238.

9. Sirard MA, Parrish JJ, Ware MI, Leibfried-Rutledge MI, First NL. The culture of bovine oocytes to obtain developmentally competent embryos. Biol Reprod 1988; 39:546-552.

10. Eyestone WH, First NL. Coculture of early cattle embryos to the blastocyst stage with oviductal tissue or in conditioned medium. J Reprod Fertil 1989; 85:715-720.

11. Fukui Y, Ono H. Effects of sera, hormones, and granulosa cells added to culture medium for in vitro maturation, fertilization, cleavage and development of bovine oocytes. J Reprod Fertil 1989; 86:501-506.

12. Fukuda Y, Ichikawa M, Naito K, Toyoda Y. Birth of normal calves resulting from bovine oocytes matured, fertilized, and cultured with cumulus cells in vitro up to the blastocyst stage. Biol Reprod 1990; 42:114-119.

13. Wiemer KE, Watson AJ, Polanski V, McKenna AI, Fick GH, Schultz GA. Effects of maturation and co-culture treatments on the developmental capacity of early bovine embryos. Mol Reprod Dev 1991; 30: 330-338.

14. Xu KP, Yadav BR, Rorie RW, Plante L, Betteridge KJ, King WA. Development and viability of bovine embryos derived from oocytes matured and fertilized in vitro and co-cultured with bovine oviductal epithelial cells. J Reprod Fertil 1992; 94:33-43.

15. Keskintepe L, Brackett BG. In vitro developmental competence of in vitro-matured bovine oocytes fertilized and cultured in completely defined media. Biol Reprod 1996; 55:333-339.

16. Keskintepe L, Burnley CA, Brackett BG. Production of viable bovine blastocyst in defined in vitro conditions. Biol Reprod 1995; 52:14101417.

17. Liu Z, Foote RH. Development of bovine embryos in KSOM with added superoxide dismutase and taurine and with five and twenty percent $\mathrm{O}_{2}$. Biol Reprod 1995; 53:786-790.

18. Gardner DK. Mammalian embryo culture in the absence of serum or somatic cell support. Cell Biol Int 1994; 18:1163-1179.

19. Eckert J, Niemann H. In vitro maturation, fertilization and culture to blastocyst of bovine oocytes in protein-free media. Theriogenology 1995; 43:1211-1225.

20. Saeki K, Hoshi M, Leibfried-Rutledge ML, First NL. In vitro fertilization and development of bovine oocytes matured in serum-free medium. Biol Reprod 1991; 44:256-260.

21. Krisher RL, Bavister BD. Enhanced glycolysis after maturation of bovine oocytes in vitro is associated with increased developmental competence. Mol Reprod Dev 1999; 53:19-26.

22. Avery B, Bavister BD, Greve T. Development of bovine oocytes, in vitro matured in a chemically defined protein-free medium, supplemented with different amino acid formulations. Theriogenology 1998; 49:306.

23. Hill JL, Wade MG, Nancarrow CD, Kelleher DL, Boland MP. Influence of ovine oviductal amino acid concentrations and an ovine oestrus associated glycoprotein on development and viability of bovine embryos. Mol Reprod Dev 1997; 47:164-169.

24. Gardner DK, Lane M, Spitzer A, Batt PA. Enhanced rates of cleavage and development for sheep zygotes cultured to the blastocyst stage in vitro in the absence of serum and somatic cells: amino acids, vitamins, and culturing embryos in groups stimulate development. Biol Reprod 1994; 50:390-400.

25. Gardner DK, Lane M. Amino acids and ammonium regulate mouse embryos development in culture. Biol Reprod 1993; 48:377-385.

26. Brison DR, Schultz RM. Apoptosis during mouse blastocyst formation: evidence for a role for survival factors including transforming growth factor $\alpha$. Biol Reprod 1997; 56:1088-1096.

27. Brison DR, Schultz RM. Increased incidence of apoptosis in transforming growth factor $\alpha$-deficient mouse blastocysts. Biol Reprod 1998; 59:136-144.

28. De la Fuente R, King WA. Use of a chemically defined system for the direct comparison of inner cell mass and trophectoderm distribution in murine, porcine and bovine embryos. Zygote 1997; 5:309320.

29. Watson AJ, Watson PH, Warnes D, Walker SK, Armstrong DT, Seamark RF. Preimplantation development of in vitro-matured and in vitro-fertilized ovine zygotes: comparison between coculture on oviduct epithelial cell monolayers and culture under low oxygen atmosphere. Biol Reprod 1994; 50:715-724

30. Parrish JJ, Susko-Parrish JL, Leibfried-Rutledge ML, Crister ES, Eyestone WH, First NL. Bovine in vitro fertilization with frozen thawed sperm. Theriogenology 1986; 25:591-600.

31. De Sousa PA, Westhusin ME, Watson AJ. Analysis of variation in relative mRNA abundance of specific gene transcripts in single bovine oocytes and early embryos. Mol Reprod Dev 1998; 49:119-130.

32. Collins JE, Fleming T. Specific mRNA detection in single lineage marked blastomeres from preimplantation embryos. Trends Genet 1995; 11:5-7.

33. Betts DH, MacPhee DJ, Kidder GM, Watson AJ. Ouabain sensitivity and expression of $\mathrm{Na} / \mathrm{K}$-ATPase $\alpha$ - and $\beta$-subunit isoform genes during bovine early development. Mol Reprod Dev 1997; 46:114-126.

34. Watson AJ, Hogan A, Hahnel A, Wiemer KF, Schultz GA. Expression of growth factor ligand and receptor genes in the preimplantation bovine embryo. Mol Reprod Dev 1992; 31:87-95.

35. Harvey MB, Arcellana-Panililio MY, Zhang X, Schultz GA, Watson 
AJ. Expression of genes encoding antioxidant enzymes in preimplantation mouse and cow embryos and primary bovine oviduct cultures employed for embryo coculture. Biol Reprod 1995; 53:530-538.

36. Walker SK, Hill JL, Kleemann DO, Nancarrow CD. Development of ovine embryos in synthetic oviductal fluid containing amino acids at oviductal fluid concentrations. Biol Reprod 1996; 55:703-708.

37. Gandolfi F, Moor RM. Stimulation of early embryonic development in the sheep by co-culture with oviduct epithelial cells. J Reprod Fertil 1987; 81:23-28.

38. Barnett DK, Bavister BD. What is the relationship between the metabolism of preimplantation embryos and their developmental competence? Mol Reprod Dev 1996; 43:105-133.

39. Wrenzycki C, Herrmann D, Carnwath JW, Niemann H. Expression of the gap junction gene connexin43 (Cx43) in preimplantation bovine embryos derived in vitro or in vivo. J Reprod Fertil 1996; 108:17-24.

40. Wrenzycki C, Herrmann D, Carnwath JW, Niemann H. Alterations in the relative abundance of gene transcripts in preimplantation bovine embryos cultured in medium supplemented with either serum or PVA. Mol Reprod Dev 1999; 53:8-18.

41. Gardner DK, Lane M, Calderon I, Leeton J. Environment of the preimplantation human embryo in vivo: metabolic analysis of oviduct and uterine fluids and metabolism of cumulus cells. Fertil Steril 1996; 65: 397.

42. Lee ES, Fukui Y. Synergistic effect of alanine and glycine on bovine embryos cultured in a chemically defined medium and amino acid uptake by in vitro produced bovine morulae and blastocysts. Biol Reprod 1996; 55:1383-1389.

43. Partridge RJ, Leese HJ. Consumption of amino acids by bovine preimplantation embryos. Reprod Fertil Dev 1996; 8:945-950.

44. Restall BJ, Wales RG. The fallopian tube of the sheep. 3. The chemical composition of fluid from the fallopian tube. Austr J Biol Sci 1966; 19:687-698.

45. Tervit HR, Whittingham DG, Rowson LEA. Successful culture in vitro of sheep and cattle ova. J Reprod Fertil 1972; 30:493-487.author $\star$ fix pages.

46. Thompson JGE, Simpson AC, Pugh PA, Donnelly PE, Tervit HR. Effect of oxygen concentration on in vitro development of preimplantation sheep and cattle embryos. J Reprod Fertil 1990; 89:573-578.

47. Goto Y, Noda Y, Mori T, Nakano M. Increased generation of reactive oxygen species in embryos cultured in vitro. Free Radical Biol Med $1993 ; 15: 69-75$

48. Dumoulin JC, Vanvuchelen RC, Land JA, Pieters MH, Geraedts JP, Evers JL. Effect of oxygen concentration on the in vitro fertilization and embryo culture in the human and the mouse. Fertil Steril 1995; 63:115-119.

49. Kobayashi K, Yamashita S, Satoh T, Hoshi H. Low oxygen and glucose improves the development of fertilized bovine oocytes in defined medium without somatic cells. In Vitro Cell Dev Biol 1994; 30:556558.

50. Lonergan P, Carolan C, Van Langendonckt A, Donnay I, Khatir H, Mermillod P. Role of epidermal growth factor in bovine oocyte maturation and preimplantation embryo development in vitro. Biol Reprod 1996; 54:1420-1429.
51. Park YS, Lin YC. Effect of epidermal growth factors and defined simple media on in vitro bovine oocyte maturation and early embryonic development. Theriogenology 1993; 39:475-484.

52. Harper KM, Brackett BG. Bovine blastocyst development after in vitro maturation in a defined medium with epidermal growth factor and low concentrations of gonadotropins. Biol Reprod 1993; 48:409-416.

53. Lorenzo PL, Illera MJ, Illera JC, Illera M. Enhancement of cumulus expansion and nuclear maturation during bovine oocyte maturation in vitro by additional of epidermal growth factor and insulin-like growth factor I. J Reprod Fertil 1994; 101:697-701.

54. Singh D, Barbe GJ, Armstrong DT. Factors influencing resumption of meiotic maturation and cumulus expansion of porcine oocyte-cumulus cell complexes in vitro. Mol Reprod Dev 1993; 36:113-119.

55. Ding J, Foxcroft GR. Epidermal growth factor enhances oocytes maturation in pig. Mol Reprod Dev 1994; 39:30-40.

56. Dekel N, Sherizly I. Epidermal growth factor induces maturation of rat follicle enclosed oocytes. Endocrinology 1985; 116:512-516.

57. Downs SM. Specificity of epidermal growth factor action on maturation of the murine oocyte and cumulus oophorus in vitro. Biol Reprod 1989; 41:371-379.

58. Wood SA, Kaye PL. Effects of epidermal growth factor on preimplantation mouse embryos. J Reprod Fertil 1989; 85:575-582.

59. Dardik A, Schultz RM. Blastocoel expansion in the preimplantation mouse embryo: stimulatory effect of TGF- $\alpha$ and EGF. Development 1991; 113:919-930.

60. Betts DH, Barcroft LC, Watson AJ. Na/K-ATPase-mediated ${ }^{86} \mathrm{Rb}+$ uptake and asymmetrical trophectoderm localization of $\alpha 1$ and $\alpha 3 \mathrm{Na} /$ K-ATPase isoforms during bovine pre-attachment development. Dev Biol 1998; 197:77-92.

61. Levesque JT, Sirard M-A. Resumption of meiosis is initiated by the accumulation of cyclin B in bovine oocytes. Biol Reprod 1996; 55: $1427-1436$.

62. Ho Y, Doberty AS, Schultz RM. Mouse preimplantation embryo development in vitro: effect of sodium concentration in culture media on RNA synthesis and accumulation and gene expression. Mol Reprod Dev 1994; 38:131-141.

63. Payton BV, Rempel R, Bachvarova R. Changes in state of adenylation and time course of degradation of maternal mRNAs during oocyte maturation and early development in the mouse. Dev Biol 1988; 129: 304-314.

64. Payton BV, Bachvarova R. Polyadenylation and deadenylation of maternal mRNAs during oocyte growth and maturation in the mouse Mol Reprod Dev 1994; 37:172-180.

65. Temeles GL, Schultz RM. Transient polyadenylation of a maternal mRNA following fertilization of mouse eggs. J Reprod Fertil 1997; 109:223-228.

66. Brevini-Gandolfi TAL, Favetta LA, Mauri L, Luciano AM, Cillo F Gandolfi F. Changes in poly(A) tail length of maternal transcripts during in vitro maturation of bovine oocytes and their relation with developmental competence. Mol Reprod Dev 1999; 52:427-433.

67. Brevini-Gandolfi TAL, Favetta LA, Mauri L, Luciano AM, Cillo F, Gandolfi F. Changes in poly(A) tail length of maternal transcripts during in vitro maturation of bovine oocytes and their relation with developmental competence. Mol Reprod Dev 1999; 52:427-433. 